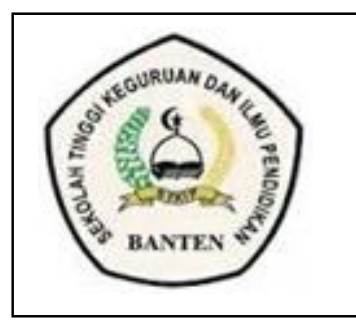

JoEE 2 (2) (2021) : 56-64

JoEE

(Journal of Earlychildhood Education)

JURNAL PENDIDIKAN GURU PENDIDIKAN ANAK USIA DINI

http://jurnal.stkipbanten.ac.id/index.php/Joe

\title{
STUDI LITERATUR PENGGUNAAN MEDIA FLASHCARD TERHADAP KEMAMPUAN MENGENAL HURUF ANAK
}

\author{
Maya Sih Hika Pamungkas ${ }^{1}$, Marini Magdalena², dan Siti Zaenab ${ }^{3}$ \\ ${ }^{1}$ Sekolah Tinggi Keguruan dan Ilmu Pendidikan Banten \\ ${ }^{2}$ Sekolah Tinggi Keguruan dan Ilmu Pendidikan Banten \\ ${ }^{3}$ SMK Insan Aqilah 2 \\ Penulis Korespondensi: hikapamungkas@gmail.com ${ }^{1}$, Marinimagdalena@gmail.com² \\ $\underline{\text { Sitizaenab688@gmail.com }}{ }^{3}$ \\ Artikel: Penggunaan Media Flashcard Terhadap Kemampuan Mengenal Huruf Anak \\ Penerima: Juli 2021 \\ Diterima: Agustus 2021 \\ Dipublikasikan: September 2021
}

\begin{abstract}
Recognition of letters in early childhood must use the method that is good and uses interesting ways so that children can really understand letters properly and correctly, therefore the most appropriate development to stimulate the development of letter recognition must stimulate children correctly. To overcome these problems, it is necessary to use media that can improve the ability to recognize letters to early childhood. One alternative to solve this problem is to carry out learning using learning media in the form of Flashcard media so that children are able to easily recognize letters correctly. The research that the researcher did was in the form of a literature study or literature study. The research used is descriptive research with a qualitative approach. Based on various sources that have been compiled by researchers, it can be seen that the use of Flashcard media to improve children's language skills in recognizing letters has increased significantly, namely the Potential of FlashCard Media on the Ability to Recognize Early Childhood Letters has had a very significant impact, very effectively applied to children. early childhood, because it provides space for early childhood to be more active in the learning process in the classroom.
\end{abstract}

Keywords: Flashcard, Language, Recognizing Letters

\section{ABSTRAK}

Pengenalan huruf pada anak usia dini harus menggunakan metode yang baik dan menggunakan cara-cara yang menarik agar anak dapat betul-betul memahami huruf dengan baik dan benar, oleh sebab itu pengembangan yang paling tepat untuk merangsang perkembangan pengenalan huruf harus menstimulus anak dengan benar. 
Maya Sih Hika Pamungkas, Marini Magdalena, dan Siti Zaenab. Studi Literatur Penggunaan Media Flashcard Terhadap kemampuan Bahasa Anak

Untuk mengatasi permasalahan tersebut, maka perlu digunakannya media yang dapat meningkatkan kemampuan mengenal huruf terhadap anak usia dini. Salah satu alternatif untuk memecahkan masalah tersebut adalah melaksanakan pembelajaran dengan menggunakan media pembelajaran berupa media Flashcard agar anak mampu dengan mudah mengenal huruf dengan benar. Penelitian yang peneliti lakukan ini berupa penelitian studi literature atau studi kepustakaan. Penelitian yang digunakan adalah penelitian deskriptif dengan pendekatan kualitatif. Berdasarkan dari berbagai sumber yang berhasil dihimpun oleh peneliti, dapat dilihat bahwa penggunaan media Flashcard untuk meningkatkan kemampuan bahasa anak dalam mengenal huruf meningkat secara signifikan, yaitu Potensi Media FlashCard terhadap Kemampuan Mengenal Huruf Anak Usia Dini telah memberikan dampak yang sangat signifikan, sangat efektif diterapkan pada anak usia dini, karena memberikan ruang bagi anak usia dini untuk lebih aktif dalam proses pembelajaran di kelas.

Kata Kunci : Flashcard, Bahasa, Mengenal Huruf

\section{PENDAHULUAN}

Pendidikan Anak Usia Dini (PAUD) memilki 6 aspek perkembangan, yaitu: agama dan moral, fisik motorik, kognitif, bahasa, sosial emosional, dan seni. Keenam aspek tersebut sangat berpengaruh terhadap perkembangan anak usia dini salah satunya adalah kemampuan mengenal angka terhadap anak usia dini. Pada masa ini anak usia dini identik dengan keceriaan, kesenangan, dan kegembiraan. Pada masa ini juga kita sering mendengar dengan kata Golden Age atau masa keemasan dimana $80 \%$ otak anak sudah bekerja dan ditandai pada perubahan dalam setiap perkembangan secara cepat baik pada fisik motorik, bahasa, kognitif, sosial emosional, moral agama dan seni.

Bahasa merupakan bagian dari aspek perkembangan anak yang harus distimulus secara optimal. Bahasa yakni suatualat untuk berpikir, mengekspresikan diri dan berkomunikasi. Keterampilan bahasa sangat penting dalam rangka pembentukan informasi, konsep dan pemecahan masalah. Serta melalui bahasa dapat memahami komunikasi perasaan dan pikiran. Dalam aspek Bahasa anak di perkenalkan huruf-huruf (abjad) untuk meningkatkan kemampuan berbahasa anak usia dini. Mengajarkan mengenal huruf di taman kanak-kanak dapat dilaksanakan selama batas-batas aturan perkembangan pra-sekolah serta mendasarkan diri pada prinsip dasar hakiki dari Pendidikan taman kanak-kanak sebagai sebuah taman bermain, sosialisasi, dan perkembangan berbagai kemampuan pra-skolatik yang lebih substansi yaitu bidang pengembangan kemampuan dasar yang meliputi kemampuan berbahasa atau membaca kognitif, fisik motorik dan seni. Apabila kita ingin mengajarkan sesuatu kepada anak/siswa dengan baik dan berhasil pertama-tama yang harus diperhatikan adalah metode atau cara pendekatan yang akan dilakukan, sehingga sasaran yang diharapkan dapat tercapai atau terlaksana dengan baik, karena metode atau cara pendekatan yang dalam fungsinya 
merupakan alat untuk mencapai tujuan. Oleh karena itu perlu adanya media pembelajaran. Media pembelajaran digunakan sebagai alat untuk menyampaikan materi pembelajaran pada siswa. Berbagai bentuk media dapat digunakan untuk meningkatkan pengalaman belajar kearah yang lebih konkret. Pengajaran dengan menggunakan media tidak hanya sekedar menggunakan kata-kata (simbol verbal), sehingga dapat di harapkan diperolehnya hasil pengalaman belajar yang lebih berarti bagi siswa.

Media pembelajaran sebenarnya memiliki fungsi yang penting, selain berfungsi membantu pemahaman siswa terhadap materi yang nantinya dapat mempengaruhi hasil belajarnya, media pembelajaran juga berfungsi sebagai pengganti seorang guru ketika guru tdak dapat memberikan materi kepada siswa karna suatu hal.

Dengan menggunakan media, diharapkan pembelajaran dikelas menjadi lebih mudah di pelajari. Penggunaan media pembelajaran berbahasa atau mengenal huruf disekolah diantaranya yaitu menggunakan media serbanika yang berupa media FlashCard (Kartu gambar), dengan menggunakan media pembelajaran hal itu bisa menjadikan proses pembelajaran lebih bervariasi.

Pada dasarnya, kemampuan mengenal huruf di Taman kanak -kanak (TK), dapat dilaksanakan dalam batasbatas aturan pra-skolastik atau praakademik.

Pembelajaran mengenal huruf di Taman Kanak-kanak hendaknya diberikan secara terpadu menurut pengembangan kemampuan dasar, dalam hal ini dalam bidang pengembangan bahasa dan motorik. Proses belajar mengajar didalam kelas merupakan tantangan tersendiri untuk guru mengoptimalkan pengajaran. Kegiatan belajar mengajar di kelas merupakan suatu dunia komunikasi tersendiri dimana guru dan anak bertukar pikiran untuk mengembangkan ide dan pengertian. Ketika proses belajar mengajar tersebut terjadi, tentu saja tidak dapat berjalan secara lancar seperti apa yag diharapkan oleh guru. Sering kali timbul gangguangangguan dan penyimpangan, sehingga kegiatan belajar mengajar tidak dapat berjalan secara efektif dan optimal.

Banyak faktor yang mendasari salah satunya adalah kurangnya minat dan kemampuan anak menerima materi ajar yang disampaikan oleh guru. Salah satu cara untuk meningkatkan kemampuan mengenal huruf anak adalah dengan mengadakan variasi belajar dalam kegiatan pembelajaran yang dilakukan. Cara mengenal huruf pada anak akan lebih efektif dengan menggunakan media gambar dan kartu huruf yang sering disebut flashcard. Dengan adanya media pembelajaran yang kreatif mengajarkan mengenal huruf akan lebih mudah dipahami dan membuat anak tidak bosan dalam kegiatan belajar mengajar. Mengenal huruf pada anak tidak tumbuh dengan sendirinya tetapi harus diasah agar anak lebih mudah dalam mengenal huruf dan siap memasuki jenjang pendidikan selanjutnya.

Di TK IT Insan Syazani bahwa kemampuan anak mengenal huruf masih kurang, banyak anak saat di tanya guru menyebutkan huruf yang di tunjuk anak masih menyebutkan dengan salah seperti huruf M di ucapkan anak huruf N. Dengan menerapkan media flashcard pada anak peneliti mengharapkan untuk kedepannya lebih mudah memahami huruf, sehingga para pendididk dapat menciptakan atau mendidik anak menjadi pribadi yang 
Maya Sih Hika Pamungkas, Marini Magdalena, dan Siti Zaenab. Studi Literatur Penggunaan Media Flashcard Terhadap kemampuan Bahasa Anak

berkualitas untuk masyarakat terutama untuk diri mereka sendiri.

Diharapkan melalui media flashcard ini kemapuan pengenalan huruf anak TK kelompok A dapat meningkat. Cara mengajarkan mengenal huruf mengacu pada karakteristik umum Anak Usia Dini, dimana aktivitas bermain menjadi aktivitas dominan mereka. Maka pelajaran mengenal huruf pada Anak Usia Dini hendaknya dilakukan dengan pendekatan yang menyenangkan dan tidak memaksa anak.

\section{LANDASAN TEORI}

\section{Pengertian Studi Literatur}

Studi literatur adalah serangkaian kegiatan yang berkenaan dengan metode pengumpulan data pustaka, membaca dan mencatat, serta mengelolah bahan penelitian. Studi Literatur juga merupakan penelitian yang dilakukan oleh peneliti dengan mengumpulkan sejumlah buku buku, majalah yang berkaitan dengan masalah dan tujuan penelitian. Teknik ini dilakukan dengan tujuan untuk mengungkapkan berbagai teori-teori yang relevan dengan permasalahan yang sedang dihadapi/diteliti sebagai bahan rujukan dalam pembahasan hasil penelitian. Pengertian Lain tentang Studi literatur adalah mencari referensi teori yang relevan dengan kasus atau permasalahan yang ditemukan. Secara Umum Studi Literatur adalah cara untuk menyelesaikan persoalan dengan menelusuri sumber-sumber tulisan yang pernah dibuat sebelumnya. Dengan kata lain, istilah Studi Literatur ini juga sangat familier dengan sebutan studi pustaka (Handriani:2017).

(C) 2021, JoEE, Jurnal of Early Childhood. PGPAUD e-ISSN: 2775-7870

\section{Belajar Dan Pembelajaran}

Belajar menurut Bell-Gredler adalah proses yang dilakukan oleh manusia untuk mendapatkan aneka ragam competensies, skills, and attitudes. Kemampuan (competencies), keterampilan (skills) dan sikap (attitudes) tersebut diperoleh secara bertahapdan berkelanjutan mulai dari masa bayi sampai masa tua melalui rangkaian proses belajar sepanjang hayat. rangkaian proses belajar itu dilakukan dalam bentuk keterlibatannya dalam pendidikan informal, keturutsertaannya dalam pendidikan formal dan/atau pendidikan nonformal. Kemampuan belajar inilah yang membedakan manusia dengan makhluk lainnya.

Chauhan mengatakan bahwa pembelajaran adalah upaya dalam memberi perangsang (stimulus), bimbingan, pengarahan dan dorongan kepada anak agar terjadi proses belajar, lebih lanjut Chauhan, mengungkapkan bahwa, "Learning is the process by which behavior (in the broader sense) is or changed through practice or training." (Belajar adalah proses perubahan tingkah laku (dalam arti luas) ditimbulkan atau diubah melalui praktik atau latihan). Belajar adalah serangkaian kegiatan jiwa raga untuk memperoleh suatu perubahan tingkah laku sebagai hasil dari pengalaman individu dalam interaksi dengan lingkungannya yang menyangkut kognitif afektif dan psikomotor.

\section{Media Pembelajaran}

Menurut Kemp dan Dayton "media pembelajaran dapat memenuhi tiga fungsi utama apabila media itu digunakan untuk perorangan, kelompok, atau kelompok pendengar yang besar jumlahnya, yaitu: (1) memotivasi minat atau tindakan, 
menyajikan informasi, dan (3) memberi instruksi”. (Kustandi, Cecep dan Sutjipto, Bambang. 2013. Media Pembelajaran; Manual dan Digital, Bogor: Ghalia Indonesia. Hal.24)

\section{Flashcard}

Menurut Doman "FlashCard adalah media pembelajaran dalam bentuk kartu bergambar yang dilengkapi huruf. Gambar yang ada pada FlashCard merupakan rangkaian pesan yang disajikan dengan keterampilan setiap gambar yang dicantumkan pada bagian belakangnya" (Ibid 2017 Pengaruh flashcard terhadap kemampuan mengenal huruf pada anak kelompok A)

Menurut Hanum "Media FlashCard adalah media pembelajaran dalam bentuk kartu bergambar yang ukurannya sekitar $5,4 \times 8,5 \mathrm{~cm}$. gambar yang ada pada media ini merupakan rangkaian pesan yang di sajikan dengan keterangannya. Media FlashCcard merupakan media yang membantu dalam mengingat dan mengkaji ulang bahan pelajaran, seperti definisi atau istilah, simbol-simbol, ejaan Bahasa, rumus-rumus dan lain-lain" (Hanum S.F 2017).

Menurut pengertian di atas dapat disimpulkan bahwa media FlashCard sangat efisien dalam mengenalkan huruf abjad pada anak usia dini, karena gambargambar yang ditampilkan pada FlashCard dapat meningkatkan kemampuan anak untuk mengingat simbol huruf-huruf abjad dengan visual yang ditampilkan.

\section{Kemampuan Mengenal Huruf}

Menurut Carol sefelt "kemampuan mengenal huruf adalah kesanggupan melakukan sesuatu dengan mengenali tanda-tanda/ciri-ciri dari tanda aksara dalam tata tulis yang merupakan anggota abjad yang melambangkan bunyi bahasa". (2008: 330-331) Kemampuan merupakan suatu kesanggupan, kecakapan untuk menguasai sesuatu yang sedang dihadapi. Sriwayuni mengemukakan bahwa kemampuan akan muncul pada diri anak yang memiliki motivasi, rasa ingin tahu dan imajinasi karena anak akan selalu mencari dan ingin menemukan jawaban.

\section{Pentingnya Mengenal Huruf}

Menurut Hasan Maemunah "Pengenalan huruf sejak usia TK yang penting adalah metode pengajarannya melalui proses sosialisasi, dan metode pengajaran membaca tanpa membebani dengan kegiatan belajar yang menyenangkan Dari pernyataan di atas bahwa mengenal huruf adalah penting bagi anak TK dan perlu diajarkan"

(Opcit:314)

\section{METODE PENELITIAN}

Menurut Sugiyono "Metode penelitian pada dasarnya merupakan cara ilmiah untuk mendapatkan data dengan tujuan dan kegunaan tertentu. Berdasarkan hal tersebut terdapat empat kata kunci yang perlu diperhatikan yaitu, cara ilmiah, data, tujuan, dan kegunaan. Cara ilmiah berarti kegiatan penelitian itu didasarkan pada ciriciri keilmuan, yaitu rasional, empiris dan sistematis. Rasional berarti kegiatan penelitian itu dilakukan dengan cara-cara yang masuk akal, sehingga terjangkau oleh penalaran manusia. Empiris berarti caracara yang dilakukan itu dapat diamati oleh indera manusia, sehingga orang lain dapat mengamati dan mengetahui cara-cara yang digunakan. Sistematis artinya proses yang digunakan dalam penelitian itu menggunakan langkah-langkah tertentu yang bersifat logis" (Sugiyono:2019). 
Maya Sih Hika Pamungkas, Marini Magdalena, dan Siti Zaenab. Studi Literatur Penggunaan Media Flashcard Terhadap kemampuan Bahasa Anak

Penelitian ini menggunakan jenis penelitian studi literatur. Studi literatur merupakan penelitian kepustakaan dan studi pustaka/riset pustaka meski bisa dikatakan mirip akan tetapi berbeda. Studi pustaka adalah istilah lain dari kajian pustaka, tinjauan pustaka, kajian teoritis, landasan teori, telaah pustaka (literature review), dan tinjauan teoritis. Meskipun merupakan sebuah penelitian, penelitian dengan studi literatur tidak harus turun ke lapangan dan bertemu dengan responden. Data-data yang dibutuhkan dalam penelitian dapat diperoleh dari sumber pustaka atau dokumen. Selain data, beberapa hal yang harus ada dalam sebuah penelitian supaya dapat dikatakan ilmiah, juga memerlukan hal lain seperti rumusan masalah, landasan teori, analisis data, dan pengambilan kesimpulan.

Penelitian dengan studi literatur adalah penelitian yang persiapannya sama dengan penelitian lainnya akan tetapi sumber dan metode pengumpulan data dengan mengambil data di pustaka, membaca, mencatat, dan mengolah bahan penelitian. Meskipun terlihat mudah, studi literatur membutuhkan ketekunan yang tinggi agar data dan analisis data serta kesimpulan yang dihasilkan sesuai dengan tujuan yang diharapkan. Untuk itu dibutuhkan persiapan dan pelaksanaan yang optimal. Penelitian studi literatur membutuhkan analisis yang matang dan mendalam agar mendapatkan hasil. Dengan demikian penelitian dengan studi literatur juga sebuah penelitian dan dapat dikategorikan sebagai sebuah karya ilmiah karena pengumpulan data dilakukan dengan sebuah strategi dalam bentuk metodologi penelitian. Variabel pada penelitian studi literatur bersifat tidak baku. Data yang diperoleh dianalisis secara (C) 2021, JoEE, Jurnal of Early Childhood. PGPAUD e-ISSN: 2775-7870 mendalam oleh penulis. Data-data yang diperoleh dituangkan ke dalam sub bab-sub bab sehingga menjawab rumusan masalah penelitianMetode atau pendekatan yang digunakan pada penelitian ini adalah pendekatan kualitatif. Pendekatan kualitatif merupakan salah satu bentuk pendekatan dalam penelitian yang banyak digunakan, terutama dalam penelitian sosial. Penelitian ini memungkinkan peneliti melakukan kajian secara komperhensif dan menyeluruh berkaitan dengan masalah penelitian.

\section{HASIL DAN PEMBAHASAN}

\section{Hasil}

Hasil Penelitian ini dilakukan untuk mengetahui pengaruh latihan Bola Gantung terhadap teknik dasar smash bola voli. Berdasarkan sumber-sumber yang relevan menunjukkan adanya pengaruh latihan Bola gantung terhadap teknik dasar smash bola voli. Hal ini dilihat dari meningkatnya teknik dasar smash. Berikut merupakan penjelasan dari sumber-sumber yang telah didapatkan:

1. Indah Puspita Sari (2020). pengaruh media flashcard terhadap kemampuan mengenal huruf pada anak kelompok a di tk it izzudin Palembang. Analisis data menggunakan Pre-Eksperimental. Hasil penelitian yang didapatkan Nilai pada setiap posttest dijumlahkan dibagi 3 didapatkan nilai rata-rata 77,7 . Sebagai data yang dihipotesiskan adalah data yang terdapat batas bawah interval nilai kategori BSH yaitu 62,5. Dari hasil analisis data diperoleh $=3,94$ nilai $=1,72$ dengan $\alpha=0,05 \mathrm{dan} \mathrm{dk}=$ 19. Dari setiap pertemuan 2 dari 3 indikator dominan yang muncul yaitu, Menyebutkan huruf yang dikenal, dan

PGPAUD JURNAL 
Meniru (Mengucapkan Huruf a-z). Sedangkan satu indikator yang kurang muncul yaitu Menunjukkan Huruf a-z.

Dapat ditarik kesimpulan bahwa penelitian melalui permainan Flashcard secara keseluruhan terbukti efektif dalam meningkatkan prestasi kemampuan mengenal huruf anak. Ini dapat dilihat melalui hasil tes lisan terjadi peningkatan kemampuan mengenal huruf anak yang signifikan.

2. Tawaduddin Nawafilaty (2017). Pengaruh media flash card terhadap kemampuan mengenal huruf pada anak kelompok $a$. Teknik pengumpulan data dalam penelitian ini menggunakan pre-eksperimental designs (Kuantitatif). Hasil yang didapat dari penelitian adalah Anak mulai mampu menyebutkan kembali huruf yang baru didengar saat guru bertanya huruf apa yang sudah disebutkan, meniru huruf dan membuat huruf dibuktikan dengan hasil anak dalam mengerjakan LKA pada pre-test dan post test. Dapat ditarik kesimpulan bahwa "Pengaruh penggunaan media flash card terhadap kemampuan mengenal huruf pada anak kelompok A" telah terbukti.

\section{Sumiati (2019) pengembangan} Pembelajaran Flash Card Berbasis Budaya Lokal Untuk Meningkatkan Kemampuan Mengenal Huruf Anak Usia Dini Di Taman Kanak-Kanak Negeri Idhata Bantaeng. Penelitian ini termasuk penelitian Research and Development atau $R \& D$. Hasil analisis lembar pengamatan aktivitas anak dalam 5 minggu efektif dan 5 kali pertemuan, serta dari lima kegiatan yang berbeda menunjukkan kategori tinggi dengan rentang nilai berada pada 2,6-3,5. Pengembangan Media Pembelajaran Flash Card Berbasis
Budaya Lokal Untuk Meningkatkan Kemampuan Pengenalan Huruf dinilai berhasil dengan pencapaian kategori tinggi, dengan presentase akumulatif yaitu $75 \%$. Pengembangan Flash Card berbasis budaya local pada anak usia dini dinilai sangat efektif digunakan dalam pembelajaran. Dapat ditarik kesimpulan bahwa dalam hal ini pengembangan media Flash Card berbasis budaya local sangat efektif digunakan dalam pembelajaran anak usia dini. Karena permainan Flash Card berbasis budaya lokal merupakan permainan yang menarik dan dapat menciptakan kesenangan bagi Anak Usia Dini.

4. Rachmawati,Riani (2016). Efektifitas flashcard dalam meningkatkan kemampuan mengenal huruf pada siswa tunarungu kelas tk-a2 di slb negeri cicendo kota bandung Teknik analisis data menggunakan eksperimen dengan pendekatan Single Subject Research (SSR)Tujuan Ditemukan bahwa penggunaan Flashcard terbukti efektif dapat meningkatkan kemampuan mengenal huruf pada siswa tunarungu (E). Hal tersebut berdasarkan dari hasil yang menunjukkan kenaikan mean level yang diperoleh $E$ pada fase baseline-1 (A-1) sebesar 39\%, 70,1\% pada fase intervensi (B), dan 79,7\% diperoleh $\mathrm{E}$ pada fase baseline-2 (A-2). Dapat ditarik kesimpulan bahwa media Flashcard dapat meningkatkan kemampuan mengenal huruf pada anak tunarungi di tk A SLB Negeri cicendo bandung.

5. Mersytiana Atu, Indri Astuti, Sri Lestari (2014). Penggunaan FlaschCard Untuk Mengenal Huruf Abjad Pada Anak Usia Dini 4-5 PGPAUD JURNAL 
Maya Sih Hika Pamungkas, Marini Magdalena, dan Siti Zaenab. Studi Literatur Penggunaan Media Flashcard Terhadap kemampuan Bahasa Anak

Tahun Di TK Pertiwi. Metode penelitian ini ialah menggunakan rancangan penelitian Tindakan Kelas (PTK) dengan menggunakan siklus tindakan. Hasil penelitian Kemampuan anak usia 4-5 tahun dalam mengenal huruf abjad meningkat sebesar $76 \%$, adapun peningkatan tersebut antara lain: Anak yang dapat menyebutkan simbol huruf abjad sebelum dilakukan tindakan sebanyak 6 anak atau 30\%, setelah dilakukan tindakkan meningkat sebanyak 14 anak atau 70\%, jadi kemampuan anak meningkat sebesar $40 \%$. Anak yang dapat mengurutkan simbol huruf abjad sebesar sebelum dilakukan tindakkan sebanyak 7 anak atau 35\%, setelah setelah dilakukan tindakkan meningkat sebanyak 17 anak atau $85 \%$, jadi kemampuan anak meningkat sebesar 50\%. Anak yang dapat menulis simbol huruf abjad sebesar sebelum dilakukan tindakkan sebanyak 7 anak atau $35 \%$, setelah setelah dilakukan tindakkan meningkat sebanyak 15 anak atau $75 \%, \quad$ jadi kemampuan anak meningkat sebesar $40 \%$. Dapat ditarik kesimpulan bahwa kemampuan mengenal huruf menggunakan Flashcard meningkat.

\section{Pembahasan}

Berdasarkan data hasil penelitian terdahulu dan melalui studi literatur yang sudah dilakukan dapat diketahui bahwa penggunakan media Flashcard dapat meningkatkan kemmapuan mengenal huruf anak.
Dalam penelitian yang telah dilakukan berupa analisa sumber-sumber yang relevan didapatkan bahwa Kemampuan mengenal huruf pada anak sudah terlihat dengan menggunakan media Flashcard. Pada prosesnya, kemampuan mengenal huruf pada anak mulai terlihat peningkatan dan antusiasnya dalam mengikuti kegiatan pembelajaran setelah menggunakan media tersebut. Begitupun pada anak sudah terlihat antusias dalam mengikuti kegiatan serta sudah mulai terlihat peningkatannya.

Dilakukannya penelitian studi literatur menggunakan beberapa sumber seperti buku- buku yang relevan dengan penelitian yang dilakukan, jurnal-jurnal maupun skripsi terdahulu yang berkaitan. Hal ini sesuai dengan teknik pengujian keabsahan data. Pengujian keabsahan data dilakukan untuk membuktikan apakah penelitian yang dilakukan benar-benar penelitian ilmiah sekaligus untuk menguji data yang diperoleh. Uji keabsahan data dalam penelitian literatur berdasarkan triangulasi data.

Teknik pengujian keabsahan data dalam penelitian deskriptif kualitatif, salah satunya menggunakan triangulasi. Triangulasi yang digunakan adalah triangulasi sumber. Beberapa sumber yang digunakan yaitu buku-buku yang berkaitan dengan variabel $\mathrm{x}$ dan $\mathrm{y}$ dalam penelitian, jurnal-jurnal dan juga skripsi. Triangulasi sumber difokuskan pada data penelitian yang telah dilakukan sebelumnya.

Setelah peneliti memilih dan mengkaji berbagai sumber yang relevan, selanjutnya peneliti mendeskripsikan hasil penelitian untuk memberi gambaran secara menyeluruh mengenai hasil penelitian dari jurnal dan skripsi terdahulu, bahwa media Flashcard berpengaruh untuk 
meningkatkan kemampuan mengenal huruf anak.

\section{PENUTUP}

\section{Simpulan}

Dengan demikian hasil penelitian ini dapat disimpulkan bahwa media Flashcard berpotensi untuk meningkatkan kemampuan mengenal huruf pada Anak Usia Dini. Karena melalui Pendekatan permainan Flashcard anak dapat lebih aktif dan memberikan pengetahuan dan pengalaman baru dalam pembelajaran.

\section{Saran}

Berdasarkan kesimpulan dari hasil penelitian, maka penelitian mengajukan saran atau rekomendasikan sebagai berikut:

1. Bagi Sekolah

Sekolah hendaknya memperhatikan standar perkembangan peserta didik yang sudah tertuang dalam kurikulum. Di samping itu hendaknya memberikan fasilitas terbaik untuk peserta didik.

2. Bagi guru

hendaknya memperhatikan setiap aspek yang ada pada setiap individu sehingga memungkin memberikan penangan sesegara mungkin dalam aspek perkembangan. Adapun dalam memberikan pembelajaran hendaknya memperhatikan bahan media yang tepat dan terbukti dalam meningkatkan aspek perkembangan.

3. Bagi Siswa

diharapkan dapat menjadikan hasil penelitian ini sebagai referensi untuk melakukan penelitian yang lebih baik lagi dengan menggunakan kegiatan bermain yang lebih menarik dalam mengembangkan kemampuan Bahasa mengenal huruf pada anak usia dini.

\section{DAFTAR PUSTAKA}

Susanto, Ahmad. (2011). Perkembangan Anak Usia Dini. Jakarta: Kencana Pernada MediaGroup.

Sunhaji. (2014). Konsep Manajemen Kelas dan Implikasinya dalam Pembelajaran. Jurnal Kependidikan, Vol. II No. 2 November 2014.

Arsyad, Azhar. (2014). Media Pembelajaran. Jakarta: PT Raja Grafindo Persada Cet-17.

Aqib, Zainal. (2013). Model-model, Media dan Strategi Pembelajaran Kontekstual (Inovatif). Bandung:Yrama Widya.

Kustandi, Cecep dan Sutjipto, Bambang. (2013). Media Pembelajaran; Manual dan Digital, Bogor: Ghalia Indonesia.

Febriani. (2012). Media Pembelajaran Untuk Anak Usia Dini. Jurnal

Kestiawan, Usep. (2016) Pengembangan Media Pembelajaran Anak Usia Dini.

Susanto, Ahmad. (2011). Perkembangan Anak Usia Dini. Jakarta: Kencana Prenada.

Alwi, Hasan. (2003). Tata Bahasa Baku Bahasa Indonesia. Jakarta: Balai Pustaka.

Neiser, Jahja. (2013). Psikologi Perkembangan. Jakarta: Prenada Media. 
Maya Sih Hika Pamungkas, Marini Magdalena, dan Siti Zaenab. Studi Literatur Penggunaan Media Flashcard Terhadap kemampuan Bahasa Anak

Arikunto. (2010) Prosedur Penelitian Suatu Pendekatan Praktek. Jakarta: Rineka Cipta.

Sugiyono. (2011) Metode Penelitian Kuantitatif Kualitatif $R \& D$. Bandung: Alfabeta

Suarifqi, Diantama. (2018) Metode Penelitian Pendidikan. Bandung: Pustaka Rahmat

Muhammad Idrus, (2011). Metode Penelitian Ilmu Sosial Pendekatan Kualitatif dan Kuantitatif, Jakarta: Erlangga,

Sunhaji. (2014). Konsep Manajemen Kelas dan Implikasinya dalam Pembelajaran.

Jurnal Kependidikan, Vol. II No. 2 November 2014.

Zaman, Badru dkk. 2012. Media dan Sumber Belajar TK. Universitas Terbuka:

Tangerang Selatan.

Tawaduddin Nawafilaty (2017). Pengaruh media flash card terhadap kemampuan mengenal huruf pada anak kelompok A, Program Studi PIAUD, Fakultas Agama Islam, Universitas Islam Lamongan.

Mersytiana Atu, Indri Astuti, Sri Lestari (2014). Penggunaan flash card untuk mengenal huruf abjad pada anak usia 4-5 tahun di tk pertiwi, PG-PAUD FKIP Universitas Tanjungpura Pontianak.
Indah Puspita Sari (2020). Pengaruh media flashcard terhadap kemampuan mengenal huruf pada anak kelompok a di tk it izzudin palembang, Program Studi Pendidikan Anak Usia Dini Fakultas Keguruan Dan IImu Pendidikan Universitas Sriwijaya. 